\title{
NOSTALGIA A MUZYKA
}

\author{
NOSTALGIA AND MUSIC
}

\author{
MAEGORZATA DYRLICA
}

\begin{abstract}
This article is an attempt to answer the question of what nostalgia is in music. The author makes a distinction between the emotions of the author, the performer and the recipient as well as the emotional qualities of the work itself. She also tries to describe the means of artistic expression that foster the impression of nostalgia in music.
\end{abstract}

Keywords: music, nostalgia, emotions, feelings

Małgorzata Dyrlica, Uniwersytet im. Adama Mickiewicza w Poznaniu, Kalisz - Polska, dyrlicama@wp.pl

ORCID ID: 0000-0001-6834-3673

Od kilku dziesięcioleci badania nad ludzkimi emocjami, dzięki nowoczesnej technologii i możliwościom obserwacji mózgu, znajdują się w nowej fazie rozwoju. Dotyczy to również badań z zakresu estetyki muzyki. To, co dotychczas było doświadczeniem i przemyśleniem filozofów muzyki, ujętym w uogólnienia trudne do zweryfikowania badaniami empirycznymi, w dużej mierze dziś zaczyna już weryfikować neurobiologia. Nowa nauka, neuroestetyka, dzięki takiemu umocowaniu, osiąga pewność siebie i optymizm, którego trudno szukać w, sięgającej dwudziestu kilku wieków, refleksji z zakresu filozofii muzyki.

Znamiennym przykładem potwierdzającym moją obserwację niech będzie stanowisko współczesnego brytyjskiego profesora filozofii i estetyki, Malcolma Budda, autora jednej z najważniejszych prac dotyczących tej problematyki i zatytułowanej tak właśnie: Muzyka i emocje. Książka przedstawia główne teorie estetyków muzyki dotyczące emocji, które autor wieńczy konkluzją: „żadna z teorii nie ocenia obiektywnie fenomenu muzyki" [Budd 2014: 10]. Książka zaś kończy się wyraźnym postulatem, niejako potwierdzającym tę "porażkę": „Jeżeli moje argumenty są słuszne, to potrzebujemy nowej teorii muzyki; i jeżeli ta nowa teoria ma coś rzeczywiście rozjaśnić, to będzie musiała, jak mniemam, przybrać formę mniej monolityczną od teorii, które w tej książce odrzuciłem" [Budd 2014: 285].

Zupełnie odmienne i dużo bardziej optymistyczne wydaje się być spojrzenie neuroestetyków. Na stawiane od wieków pytanie filozofii o piękno, w tym 
wypadku piękno w muzyce, odpowiadają po prostu przeprowadzając eksperymentalne badania dotyczące aktywności poszczególnych obszarów mózgu. „Wychodząc z założenia, że uznawanie piękna jest uniwersalną czynnością umysłową" [Przybysz 2013: 132] polecili badanym klasyfikować utwory według kategorii: piękny - neutralny - brzydki. Pozwoliło to zlokalizować "sieć połączeń neuronalnych, której aktywność związana jest z pięknem [...]" [Przybysz 2013: 133]. Stąd już tylko krok do tego, by komputerom zlecić tworzenie utworów muzycznych, które będą odpowiednio aktywizować poszczególne sieci połączeń neuronalnych i odpowiedzą na zapotrzebowanie na muzyczne piękno poszczególnych grup odbiorców, np. bywalców filharmonii, fanów disco polo, entuzjastów jazzu itd. Już powstają programy ułatwiające tworzenie utworów muzycznych, np. program Google Magenta, którego celem jest wykorzystanie opracowanych algorytmów sztucznej inteligencji do tworzenia sztuki.

Odkrycia neurobiologów pomagają również w sformułowaniu praw rządzących percepcją muzyki. I tak np. prawo Webera-Fechnera, w odniesieniu do tejże percepcji, można zinterpretować następująco: „w otoczeniu wielu zdarzeń dźwiękowych o teoretycznie wysokim poziomie napięcia każde kolejne zdarzenie o podobnych parametrach będzie traktowane jako generujące znacznie mniejsze napięcie, niż gdyby wystąpiło ono w otoczeniu zdarzeń łagodnych" [Foltyn 2013: 71]. Zastosowanie tego rodzaju praw, także np. zastosowanie modelu konsonansowości w pracy kompozytora, według entuzjastów badań neurofizjologicznych, może zupełnie zmienić warsztat kompozytorski: „Można sobie wyobrazić, że w przyszłości zostanie opracowany program, w którym kompozytor będzie na początku definiował trajektorię (formę) utworu, a potem pracował $\mathrm{w}$ ramach propozycji podanych przez komputer nad kolejnymi fragmentami dzieła, zgodnie z zadaną trajektorią" [Foltyn 2013: 74]. Decyzje twórcy, zapamiętane przez komputer, z czasem umożliwiłyby maszynie zastąpienie człowieka i „komponowanie” utworów uwzględniających nawet tzw. „rys indywidualny” poszczególnych kompozytorów. To oczywiście przekracza horyzont tradycyjnej estetyki, dla której tworzenie, nawet w czasach najbardziej radykalnej awangardy, to jednak zawsze „świadoma czynność ludzka”.

Sytuacja wydaje się o tyle trudna, że pomiędzy jedną i drugą grupą badaczy zdaje się istnieć niewiele „sieci połączeń". Neuroestetycy nie mają potrzeby zagłębiania się w "bezpłodne” dywagacje filozofów, filozofowie zaś nie mają narzędzi i przygotowania, by przeprowadzać badania mózgu. Jedni posiedli wiedzę, że "piękne jest to, co przyjemne dla wzroku i słuchu” i nie widzą potrzeby, by podważać ową prostą definicję, stwarzającą olbrzymie pole do eksperymentalnych badań nad pięknem. Drudzy wiedzą, że tę, znaną od starożytności definicję sofistów, podważali już Platon i Arystoteles, i patrzą na eksperymenty neurobiologów, w najlepszym razie, z pobłażaniem. 
Do zagadnienia nostalgii w muzyce również podejść można dwojako, podobnie jak do problemu wszelkich związków emocji i muzyki. Można szukać ustaleń ",tradycyjnych" estetyków na temat emocji, w tym wypadku nostalgii, ich teorie podważać lub dodawać do nich własne obserwacje i przemyślenia, można też przeprowadzać eksperymenty na konkretnej grupie badanych, a nawet uwiarygadniać je testami neurofizjologicznymi. Postaram się pójść drogą pośrednią i zebrać przemyślenia i ustalenia jednej i drugiej grupy badaczy, a także podzielić się własnymi spostrzeżeniami na ten temat. Nie będę w tym miejscu przeprowadzać badań empirycznych, ale wykorzystując te, które już zostały przeprowadzone, chciałabym aktualną wiedzę usystematyzować, tworząc coś w rodzaju ogólnego zarysu na temat nostalgii w muzyce. O ile bowiem istnieją publikacje na temat muzycznych emocji, to zagadnienie nostalgii, według mojej wiedzy, nie było dotąd traktowane odrębnie. Chciałabym też wskazać na pewne trudności w rozumieniu tak ogólnie sformułowanego problemu, które dotyczą braku rozróżnienia pomiędzy ludzkimi emocjami, a jakościami emocjonalnymi samego dzieła. Myślę, że właśnie brak tego rozróżnienia jest częstą przyczyną nieporozumień między badaczami, które dotyczą nie tylko badań nad nostalgią, ale w ogóle nad emocjami w muzyce. Zamierzam przyjrzeć się nostalgii doświadczanej przez kompozytora, wykonawcę i słuchacza, a zwłaszcza nostalgii samego dzieła muzycznego i środkom, dzięki którym utwór może posiadać taki właśnie charakter. Niestety, ze względu na ograniczoną objętość artykułu, tekst ma charakter ogólny i nie posiada rozwiniętej części ilustracyjnej.

Tradycyjna definicja nostalgii jest wąska, zgodna z grecką etymologią tego słowa (gr. vóøtos, powrót do domu i ä $\lambda$ үos, ból), to tęsknota za krajem ojczystym. Zatem to uczucie smutku, poczucia straty, dotyczące tych, którzy musieli opuścić ojczyznę, dawniej kojarzone nawet z chorobą psychiczną, ze względu na skutki wywołane długotrwałym obniżeniem nastroju czy depresją. Obecnie pojęcie to uległo poszerzeniu, oznacza wszelką tęsknotę, i łączy w sobie czas teraźniejszy i przeszły. Nie ma też tak destrukcyjnych konotacji jak niegdyś. Psychologia wskazuje także na pozytywne skutki nostalgii, która poprzez pamięć o tym, co było dobre, pomaga lepiej radzić sobie z teraźniejszością. Nostalgia może dotykać wszystkich ludzi w każdym wieku i znajduje swój wyraz w kulturze i sztuce.

Muzyka pośród wszystkich sztuk jawi się jako ta, która w sposób szczególny ma moc wywoływania w nas emocji. To ona najczęściej wywołuje nasze wzruszenie, towarzyszy ważnym wydarzeniom naszego życia, wprowadza nas w odpowiedni dla tych wydarzeń nastrój, podnosi rangę chwili. To przednaukowe przeświadczenie potwierdzają badania. „Muzyka w dużo większym stopniu niż statyczne obrazy, charakterystyczne dla części sztuk wizualnych, jest zdolna wywoływać wyjątkowo silne emocje [Panksepp, Bar- 
natzky 2002, s. 137; Koelsch 2012, s. 203], a słuchanie szczególnie przyjemnej muzyki aktywuje tzw. ośrodki nagrody [por. np. Blood, Zatorre, 2001; Levitin, 2005]" [Podlipniak, Przybysz 2013: 21]. Jedną z najbardziej powszechnych emocji, jakie wywołuje muzyka, jest właśnie nostalgia.

Prawie wszyscy badacze zgadzają się co do tego, że muzyka w sposób wyjątkowy wpływa na nasze emocje. Wyjątkiem jest Nick Zangwill, który twierdzi, że muzyka nie ma nic wspólnego z emocjami, gdyż to, co nami porusza nie jest muzyką, a wręcz odrywa naszą uwagę od muzyki [Zangwill 2004]. To stanowisko jest jednak odosobnione, a skuteczną polemikę przeprowadził z Zangwillem polski filozof Krzysztof Guczalski [2015]. Choć trudno zakwestionować sam wpływ muzyki na nasze emocje, to już mechanizm tego wpływu rodzi wśród badaczy liczne kontrowersje.

Przyczyn tak silnego oddziaływania muzyki upatruje się często w tym, że nie odwołuje się ona wprost do świata realnego, a jej język, czy raczej parajęzyk, bo pozbawiony semantycznych odniesien, potrafi wyrazić to, czego nie umie wyrazić język werbalny. Nie chcę zajmować się tutaj zagadnieniem, w jaki sposób muzyka na nas oddziałuje. Estetyka muzyki na przestrzeni wieków sformułowała wiele teorii na ten temat. Jest to zresztą przedmiotem jednego z najdonioślejszych sporów w historii tej dyscypliny. Jedną stroną sporu są formaliści, np. Eduard Hanslick, którzy siłę tego oddziaływania przypisują czysto muzycznym środkom, drugą zaś stroną są zwolennicy ekspresjonizmu, którzy siłę oddziaływania muzyki upatrują głównie w emocjach, które pochodzą od twórcy (Deryck Cooke) lub od wykonawcy (Vladimir Konečni) dzieła muzycznego. Emocje te są - według kognitywistów - odczytywane przez odbiorcę (Peter Kivy), lub powodują "zarażenie się" nimi przez słuchacza (John Dewey, Benedetto Croce, Robin Colingwood), np. na zasadzie korespondencji (Edmund Gurney).

Nie ma też zgody co do funkcji emocji w odbiorze muzyki - według części badaczy muzykę słuchamy wyłącznie ze względu na emocje, jakie jest zdolna w nas wywołać, według innych, do których sama się zaliczam, słuchamy jej ze względu na piękno. Ale jeśli nawet zgodzimy się z Władysławem Stróżewskim, że racją (jedyną!) istnienia muzyki jest piękno [2002], to przecież słuchamy jej właśnie dlatego, że na muzyczne piękno nie pozostajemy obojętni, lecz wywołuje ono w nas określone emocje.

Nie można jednak, jak sądzę, wiązać explicite siły emocjonalnej muzyki z jej wartością. Dowodzi tego cała historia muzyki, w której trwałe miejsce znajdują różne nurty i style, od "romantyzujących”, bardzo emocjonalnych, do "obiektywizujących", konstruktywistycznych, intelektualnych, unikających epatowania emocjami. Co więcej, nadmiernie nagromadzenie silnych jakości emocjonalnych w utworze jest jedną z cech kiczu muzycznego. Paradoksalnie zresztą, muzyka przesadnie emocjonalna, np. ckliwa, sentymen- 
talna lub przeciwnie - pompatyczna, nadęta albo histeryczna, rozpięta pomiędzy często zmieniającymi się skrajnymi emocjami, zgodnie z przytaczaną wyżej interpretacją prawa Webera-Fechnera, zwykle wcale nas nie porusza, lecz co najwyżej wywołuje rozdrażnienie.

Zawiodły też podejmowane $\mathrm{w}$ historii próby znalezienia prostych odniesień pomiędzy konkretnymi zwrotami (terms) tonalnego języka harmonicznego muzyki a ludzkimi reakcjami emocjonalnymi. Najważniejszą próbę stworzenia takiego „słownika emocji”, w którym słowa zostałyby zastąpione przez określone muzyczne zwroty podjął, w połowie XX wieku, Deryck Cooke [1959]. Cooke zawęził swoje badania do języka tonalnego, czyli pominął muzykę innych kultur, a także muzykę spoza systemu dur-moll, a także nie uwzględnił różnic kulturowych, gdyż uważał, że badane przez niego relacje są ponadkulturowe. „Słownik" Cooke'a, pomimo iż zawiera pewne trafne spostrzeżenia, okazał się być całkowicie bezradny wobec ilości, subtelności i odcieni emocji, jakie jest zdolna wyrazić muzyka, i de facto ogranicza się do identyfikacji zaledwie dwóch z nich: cierpienia i radości.

Wydaje się, że na podobne trudności badawcze natrafia dziś neurobiologia. Nawet jeśli zlokalizujemy ośrodki nagrody, jakie aktywizują się podczas słuchania pięknej muzyki, to nie sposób, za pomocą dostępnej aparatury, wyodrębnić takie cechy, struktury czy zwroty samej muzyki, które czynią ją piękną. Nie znamy przepisu na muzyczne piękno, nie jesteśmy w stanie opisać jego subtelności i odcieni, możemy tylko - podobnie jak Cooke - zidentyfikować kilka fundamentalnych zasad dobrej kompozycji. A przecież tylko piękna muzyka potrafi nas prawdziwie poruszyć i to właśnie dążenie do piękna wydaje się być podstawową zasadą komponowania. Muzyka musi dobrze brzmieć - decydująca jest wartość artystyczna samej muzyki - i żadne przesłanie, manifest czy dedykacja nie uratuje muzyki, która źle brzmi. Podobnie żadne emocje - ani kompozytora, ani wykonawcy, ani jakości emocjonalne samej muzyki nie decydują o jej wartości. Celnie ujął to Grzegorz Turnau w jednym z wywiadów:

\footnotetext{
- No dobrze, mówiąc uczciwie, jestem nie najgorszym wokalistą, dość dobrze gram na fortepianie i mam świadomość ciągu logicznego w komponowaniu. Cała reszta to jedna wielka zagadka. Dlaczego ludzie chcą tego słuchać, dlaczego przychodzą od wielu lat na koncerty i reagują pozytywnie? Nie wiem. Nie stwarzam fałszywych nadziei, nie jestem prorokiem, nie mam zresztą takich potrzeb. Natomiast to, że mam kontakt z ludźmi i oni chcą mnie słuchać, jest być może głównym motorem napędowym mojego życia.

- Na czym polega świadomość ciągu logicznego w komponowaniu?

- Sztuka jest dziełem umysłu, a nie tak zwanych emocji. Zawsze mnie irytowały stwierdzenia, że w sztuce najważniejsza jest prawda. Prawda to śmierć, reszta to złudzenia. A sztuka to spór ze śmiercią. Nie ma czegoś takiego jak prawda w sztuce.
} 
Sztuka to jest sztuczność, forma. I dopiero kiedy jest zrobiona dobrze, wywołuje w nas emocje, zachwyca, podnieca. Natomiast sama emocja nie jest sztuką i nigdy nią nie była. Bez względu na to, czy mówimy o miedziorycie, czy kantacie. Nic na to nie poradzę [Turnau 2016].

Można, jak sądzę, powiedzieć, że dla muzyki naczelną wartością, która legitymizuje jej istnienie jest piękno, a nie emocje. Piękno osiągnięte za pomocą kunsztu artystycznego. Z drugiej strony jednak to właśnie piękna muzyka zdaje się najlepiej wyrażać ludzkie emocje. Bogactwo odcieni tego piękna sprawia zaś, że tę samą emocję muzyka może wyrazić na wiele różnych sposobów, jednak nie jest ona po prostu narzędziem do wywoływania emocji. Coraz lepiej radzimy sobie z badaniem ludzkich emocji, ale wciąż tajemnicą jest zasada muzycznego piękna - to jest to „nie wiem”, o którym mówi Turnau i wielu innych kompozytorów.

Co można dziś orzec o naturze muzycznych emocji? Myślę, że przede wszystkim należy je wyraźnie oddzielić od emocji twórcy, wykonawcy i słuchacza. Każdy z tych podmiotów wnosi własne emocje w proces tworzenia, wykonywania lub wysłuchania utworu, ale istnieje w samym dziele muzycznym coś, co nie jest emocją żadnego z tych podmiotów, ale jest możliwe do uchwycenia przez każdy z nich. Skłonna jestem nazywać to, za Romanem Ingardenem, jakościami emocjonalnymi dzieła muzycznego [Ingarden 1970]. O tym, że są one niezależne od uczuć perceptora świadczy fakt, że kwalifikujemy poszczególne utwory jako wesołe, smutne, żartobliwe itd., choć sami podczas słuchania tych utworów możemy odczuwać odmienne emocje. Nie zawsze proste jest oddzielenie emocji poszczególnych podmiotów od jakości emocjonalnych samego dzieła. Zdarza się, że słuchacz jak gdyby „rzutuje” własne uczucia na dzieło i przypisuje mu własne emocje.

Jakości emocjonalne do dzieła muzycznego nie przynależą i są niezależne od stanów emocjonalnych kompozytora, wykonawcy i odbiorcy. Tkwią one niejako w samym dziele, ale są tam in potentia, tzn. trzeba je tam odnaleźć, usłyszeć, choćby słuchem wewnętrznym. Jednak nawet, gdy aktualnie nikt ich nie znajduje i nie słyszy, to tkwią tam one stale, bo są immanentną cechą danego dzieła muzycznego. Cechą - czy, jak pisze Ingarden - „niedźwiękowym momentem dzieła muzycznego" [Ingarden 1970: 252]. Ich niedźwiękowość wynika m. in. z tego, że są one nieprzemijające, trwałe - inaczej niż dźwięk czy wykonanie lub wysłuchanie utworu muzycznego, które jest zawsze przemijające i nietrwałe.

Specyfika jakości emocjonalnych polega na tym, że każdy wykonawca i każdy odbiorca znajduje je tam indywidualnie, ale są one intersubiektywnie dostępne zawsze i dla każdego w stopniu, jaki wyznacza mu jego otwartość i wrażliwość na muzykę. Może się zdarzyć, że ktoś odnajdzie w utworze muzycznym takie jakości emocjonalne, jakich nikt w nim jeszcze nie znalazł. 
Zdarza się przecież, że słyszymy, iż ktoś tak wykonał utwór muzyczny, jak nikt inny przed nim, i że swoim wykonaniem zaskoczył i zachwycił nawet samego kompozytora. Ta specyfika dzieła muzycznego otwiera mu drogę do ponadczasowości - każda epoka może poszukiwać takich jakości emocjonalnych dzieła, które są jej najbliższe. Dzięki temu jest ono jakby ciągle żywe pozostając niezmienne, ukazuje jednak swoje ciągle nowe oblicze w różnych interpretacjach. Uważam, że stopień otwartości dzieła muzycznego na rozmaite interpretacje jest jednym z ważnych wskaźników jego artystycznej wartości. Z kolei każda interpretacja znajduje nieskończoną ilość konkretyzacji w percepcji poszczególnych słuchaczy.

Ludzkie emocje związane są zawsze z pojawieniem się jakiejś myśli. I tak smutna myśl wywołuje w nas smutek, radosna myśl - radość itd. Co ciekawe, jakości emocjonalne dzieła muzycznego nie są związane z żadną myślą. Istnieją $\mathrm{w}$ dziele $\mathrm{w}$ postaci pozbawionej jakichkolwiek realnych odniesień i realnych obiektów. Oczywiście mam na myśli muzykę czystą, bez tekstu i tytułu, który sugerowałby jakieś emocje. Tytuł lub tekst może kierować naszą myśl w stronę zasugerowaną przez autora, ale nie musi - możemy podczas słuchania abstrahować od wszelkich sugestii werbalnych i skupić się wyłącznie na muzyce.

Podczas percepcji muzyki możemy odnosić jej jakości emocjonalne do własnych przeżyć psychicznych i w tym celu poszukiwać takiego rodzaju muzyki, która z nimi niejako „współbrzmi”. I tak np. doświadczając smutku możemy słuchać smutnego utworu, który wyraża nasz stan emocjonalny. Wówczas odnosimy jakości emocjonalne dzieła do konkretnego obiektu przedmiotu naszego smutku. Jednak nie zmienia to w żaden sposób samych jakości emocjonalnych, które pozostają pozbawione takich odniesień. Każdy z nas może poszukiwać dowolnych odniesień, ale możemy też doświadczać czystych jakości emocjonalnych samej muzyki - jakby smutku samego w sobie, „czystego smutku”. Trafnie, jak sądzę, pisał o tym Arthur Schopenhauer, gdy zauważał, że muzyka nie przedstawia czyichś określonych uczuć: uciechy, zmartwienia, przerażenia, radości, wesołości, spokoju ducha, lecz „samą uciechę, samo zmartwienie, samo przerażenie, samą radość, samą wesołość, sam spokój ducha, niejako in abstracto wyraża to, co w nich istotne bez wszelkich dodatków, a więc także bez motywów po temu" [1994: 404].

Mówiąc w pewnym uproszczeniu: o ile ten pierwszy sposób słuchania, nastawiony na doświadczanie emocji, poszukujący dla nich realnych odniesień, jest przedmiotem zainteresowania ekspresjonistów, to formaliści przyznają pierwszeństwo percepcji muzyki w postaci czystej, pozbawionej pozamuzycznych odniesień, lub wręcz deprecjonują inny sposób słuchania jako nieprawidłowy, prowadzący do zafałszowania dzieła muzycznego.

To rozróżnienie sposobów słuchania uważam za niezwykle istotne dla badań nad percepcją i emocjami w muzyce. I tak np. panujący wśród estetyków 
pogląd, że te emocje nie są tak silne jak emocje w świecie realnym, niekoniecznie odnosi się do sytuacji, gdy podczas słuchania "rzutujemy” nasze własne emocje na jakości emocjonalne dzieła muzycznego. Możemy wówczas jako słuchacze doświadczać emocji równie silnych jak w realnym świecie - np. rozpaczy, smutku, nostalgii. Są to jednak, jak sądzę, sytuacje wyjątkowe.

Tak więc określenie: „emocje w muzyce” lub „emocje muzyczne” to pojęcie szerokie, a przez to często nieprecyzyjne. Może dotyczyć emocji kompozytora, wykonawcy, słuchacza, a także jakości emocjonalnych samego dzieła. Tylko te ostatnie nie podlegają przemianom, są składową samego dzieła jakby w potencjalności, ale wymagają odbiorcy, który je w tym dziele odnajdzie.

To rozróżnienie jest istotne dla analizy wszelkich emocji związanych z muzyką, także nostalgii. I tak np. kompozytor pisząc dzieło muzyczne może odczuwać nostalgię i chcieć ją wyrazić w swoim dziele. Wiemy o tym z pewnością tylko wówczas, gdy nas o tym expressis verbis poinformuje, np. w tytule swojego utworu. Tak było w wypadku Poloneza a-moll Pożegnanie Ojczyzny - Les Adieux à la Patrie Michała Kleofasa Ogińskiego, pisanego przez niego w 1794 roku na emigracji, gdy po klęsce powstania kościuszkowskiego, w którym brał udział, wyjechał do Wenecji, a jego majątek skonfiskowano.

Może być też tak, jak w wypadku innego polskiego kompozytora, Fryderyka Chopina, którego cała twórczość w opinii wielu słuchaczy i teoretyków muzyki, przesycona jest nostalgią. Chopin nie pisał muzyki programowej, a o jego tęsknocie za ojczyzną świadczą $\mathrm{m}$. in. listy, np. z Wiednia do Jana Matuszyńskiego z dn. 26 XII 1930 roku:

[...] wszystkie obiady, wieczory, koncerta, tańce, których mam po uszy, nudzą mnie: tak mi tu smętno, głucho, ponuro [...]. W salonie udaję spokojnego, a wróciwszy do domu piorunuję na fortepianie [...], gdybym mógł, wszystkie bym tony poruszył, jakie by mi tylko ślepe, wściekłe, rozjuszone nasłało czucie, aby choć w części odgadnąć te pieśni, których rozbite echa gdzieś jeszcze po brzegach Dunaju błądzą, co wojsko Jana śpiewało [...], przeklinam chwilę wyjazdu [Encyklopedia muzyczna 1984: 113].

Rola wykonawcy polega na ukazaniu słuchaczom owej jakości emocjonalnej samego dzieła, jaką może być nostalgia. Nie musi on wcale aktualnie jej odczuwać, chodzi raczej o coś, co nazwałabym empatią, a więc terminem dotąd zarezerwowanym dla relacji interpersonalnych. Wykonawca jakby „wczuwa się w dzieło" podczas pracy nad jego interpretacją, dzięki czemu wychwytuje jego jakości emocjonalne. Sam, podczas wykonywania utworu, nie może już jednak całkowicie poddać się emocjom, gdyż uniemożliwiłoby to mu prawidłowe wykonanie. Choć jakości emocjonalne, jakie w dziele uchwycił, mogą mieć wpływ na jego własne emocje, podobnie jak sytuacja występu publicznego i stresu może sprzyjać pobudzeniu emocjonalnemu, wykonawca musi mieć pełną kontrolę nad własnymi emocjami. 
Jak wykonawca rozpoznaje w dziele określoną jakość emocjonalną? Myślę, że dzieje się to intuicyjnie i - podobnie jak zdolność do odczuwania empatii - jest zależne od indywidualnych cech wykonawcy. Zależy na pewno od jego osobistej wrażliwości, doświadczeń, dojrzałości i stanowi jeden z najważniejszych warunków waloryzujących jakość i tzw. głębię jego interpretacji. Jednak jakości emocjonalne, jakie ma przekazać np. nostalgia muszą istnieć w samym dziele, analizowanie życiorysu twórcy lub jego wypowiedzi nie sprawi, że w tym dziele ujawni się nowa jakość, choć czasami może ono pomóc wykonawcy tę, ukrytą dotąd dla niego, jakość emocjonalną odnaleźć. Nie trzeba znać życiorysu Chopina, by w jego muzyce usłyszeć „polskość”, tęsknotę, nostalgię...

Podobnie jak w wypadku empatii, rozpoznanie jakości emocjonalnych dokonuje się nie drogą analizy, lecz intuicji. Ale w obydwu wypadkach możemy też wskazać na pewne obiektywne zjawiska, które cechują osobę przeżywającą określoną emocję czy, respectivo, określoną jakość emocjonalną w danym dziele muzycznym. Co ważne, im bardziej złożona emocja, lub odpowiednio jakość emocjonalna, tym trudniej o jednoznaczność w jej zidentyfikowaniu. Ponadto ekspresyjność wielu utworów jest niejednoznaczna, zmienna w przebiegu tych utworów, również język służący opisywaniu emocji w muzyce jest często zbyt ubogi, mówi się wręcz, że "muzyka wyraża to, czego się nie da wyrazić słowami”. To wszystko sprawia, że opis środków, dzięki którym kompozytor osiąga efekt w postaci zamierzonej przez siebie jakości emocjonalnej, jest zawsze niedoskonały. A dodać należy, że określona jakość emocjonalna może pojawić się w dziele również w sposób nieintencjonalny.

O ile ilość utworów muzycznych, o których wiemy, że w intencji kompozytora mają mieć charakter nostalgiczny, o czym świadczy ich tytuł lub tekst, jaki im towarzyszy, jest relatywnie niewielka, to całkiem odmiennie jest w sytuacji, gdy chodzi o postrzeganie nostalgii w muzyce przez słuchaczy. Neurobiolodzy ustalili już, jakie ośrodki w mózgu aktywowane są wówczas, gdy muzyka wywołuje w nas uczucie nostalgii. Są to przede wszystkim: prążkowie w prawej półkuli i korze oczodołowej, hipokamp, brzuszno-przyśrodkowa kora przedczołowa i kora przyhipokampowa [Przybysz 2013: 131].

W przeprowadzonych w roku 2014 przez Liila Taruffi'ego i Stefana Koelscha badaniach za pomocą Internetu na grupie 772 osób (495 kobiet i 277 mężczyzn) z całego świata, w wieku 16-78 lat, przedmiotem zainteresowania były uczucia słuchaczy wywołane przez słuchanie muzyki, którą uważali za smutną [Taruffi, Koelsch 2014]. Okazało się, że, paradoksalnie, gdy czujemy się smutni i samotni, słuchamy częściej smutnej, a nie wesołej muzyki. Dotyczy to zwłaszcza osób o wyższej empatii i niższej stabilności emocjonalnej. Ale - jak pokazują te same badania - właśnie słuchanie smutnej muzyki ma wówczas dla nas korzystne efekty emocjonalne. Badania potwierdziły, że słu- 
chanie smutnej muzyki związane jest z wielowymiarowym doświadczeniem wynagradzania, a mianowicie $\mathrm{z}$ :

1. „nagrodą wyobraźni” („wyobrażam sobie, że mam taką samą, bogatą zdolność ekspresji jak muzyka"),

2. "nagrodą regulacji emocjonalnej" (lepszym samopoczuciem),

3. empatią („lubię współczuć ze smutkiem wywołanym przez muzykę, jakby to była inna osoba"),

4. brakiem konsekwencji kontekstowych („,mogę cieszyć się czystym odczuciem smutku, nie tak brutalnym i intensywnym jak w prawdziwym życiu") [Taruffi, Koelsch 2014: 4].

Najbardziej zaskakującym rezultatem tych badań było jednak odkrycie, że najczęstszym uczuciem wywoływanym przez słuchanie smutnej muzyki jest właśnie nostalgia:

Badanie obejmowało element, w odpowiedzi na który uczestnicy wskazywali najczęstsze emocje wywołane przez smutną muzykę. Mogli wybrać więcej niż jedną opcję i/lub dodać alternatywne odpowiedzi. Niespodziewanie nostalgia (76\%), a nie smutek $(44,9 \%)$ była wskazywana jako najczęstsza emocja wywoływana przez muzykę [Taruffi, Koelsch 2014: 4].

Te wskaźniki były jeszcze wyższe dla Europy Zachodniej. „W badaniu przeprowadzonym przez Juslina, Liljeströma, Västfjälla, Barradasa i Silvę (2008) odkryto, że [...] nostalgię-tęsknotę można odczuć częściej w wyniku słuchania muzyki niż w codziennych sytuacjach życiowych, w których brak bodźca muzycznego" [Przybysz 2013: 130].

Okazało się też, że motywacją do wyboru słuchania smutnej muzyki jest często chęć wywołania wspomnień. Smutna muzyka ułatwia „odzyskiwanie wspomnień", zwłaszcza gdy jest autobiograficznie ważna dla słuchacza („Barrett i współpracownicy stwierdzili, że autobiograficzne znaczenie konkretnej melodii było najsilniejszym czynnikiem powodującym intensywność nostalgii wywołanej muzyką" [Taruffi, Koelsch 2014]). Zarazem podkreślić trzeba, że nostalgia nie jest jednoznacznie smutnym uczuciem: „Nostalgia została scharakteryzowana jako «bittersweet» emocja, ponieważ zawiera jednocześnie pozytywne i negatywne aspekty, takie jak radość i smutek" [Taruffi, Koelsch 2014]. Tęsknota za tym, co minione niesie w sobie i żal nad upływającym czasem, i radość, że czas miniony był też czasem dobrym. W ten sposób w nostalgii łączy się to, co przeszłe $z$ tym, co obecne, to, co smutne z tym, co radosne, to, co bezpośrednio nas dotyka z dystansem do siebie, innego człowieka i świata, jaki stwarza czas.

Wydaje mi się, że muzyka w stopniu znacznie wyższym niż inne sztuki jest zdolna uchwycić tę niejednoznaczność nostalgii. Absolutnie nie zgadzam się z opinią niektórych badaczy (np. Jenifer Robinson), że muzyka nie jest 
w stanie oddać emocji kognitywnie złożonych. Wydaje się być wręcz przeciwnie - właśnie brak wyraźnych odniesień do rzeczywistości, jaki cechuje jakości emocjonalne muzyki, sprzyja, w mojej opinii, wyrażaniu przez nią uczuć niejednoznacznych i złożonych, trudnych do opisania werbalnego. $\mathrm{Na}$ swoistą "czystość" jakości emocjonalnych muzyki, spowodowanej brakiem konotacji kontekstowych, łatwiej jest odbiorcy, jak sądzę, „nałożyć” swoje własne, niejednokrotnie złożone i ambiwalentne uczucia.

Ułatwia to dodatkowo fakt, na który zwrócił uwagę Jerome Singer, że muzyka bardziej niż inne sztuki sprzyja tzw. „,błądzeniu myśli” [por. Singer 1975]. Wydaje mi się, że owo „błądzenie myśli" dotyczy raczej tego, co minione aniżeli tego, co przyszłe, a zatem i sprzyja odczuwaniu przez słuchacza nostalgii.

Jakie cechy posiada muzyka, którą kwalifikować można jako nostalgiczną? Jakich środków używa kompozytor? Spróbuję wymienić kilka takich środków, pamiętając jednak o „porażce Cooke'a”. Jeśli chodzi o charakter jest to muzyka liryczna, zwykle kameralna, raczej smutna. Jak trafnie zauważa Ots Kolk Bouswma: „Smutna muzyka ma pewne cechy charakterystyczne ludzi, którzy są smutni. Jest raczej wolna, nie skoczna, w tonach niskich, nie dźwięcznych. Ludzie, którzy są smutni poruszają się wolniej, mówią ciszej i niższym głosem" [Bouwsma 1950: 95]. Dodać trzeba, że jest to najczęściej muzyka napisana $\mathrm{w}$ tonacjach mollowych, oparta na niewielkich interwałach, zazwyczaj w artykulacji legato, dynamice do mezzoforte. Jednak złożoność uczucia nostalgii, która jest pogodniejszym uczuciem niż czysty smutek sprawia, że możemy w niej odnaleźć również tonacje durowe, barwę jasną, dynamikę głośniejszą, tempa żywsze, ale nie w górnych granicach temp.

Istotną rolę, jeśli chodzi o wywołanie uczucia nostalgii, jak sądzę, odgrywa kolorystyka utworu, a zwłaszcza samo brzmienie instrumentu, na jaki dany utwór jest przeznaczony. Są instrumenty, których sama barwa kojarzy się z nostalgią, gdyż nie są już powszechnie używane, ale - dzięki starym filmom - wiemy, że niegdyś były popularne, znamy ich brzmienie i kojarzymy $\mathrm{z}$ czasem minionym. Tak jest $\mathrm{np}$. z brzmieniem starego fortepianu czy bandeonu. Myślę, że o wiele trudniej osiągnąć takie wrażenie za pomocą instrumentarium elektronicznego.

Ostatnim ze środków, na jaki chciałabym zwrócić uwagę, jest forma utworu. W nostalgię wpisany jest powrót, zwracanie się myślą do czasów minionych. Muzyka jako sztuka operująca czasem, dzięki zabiegowi repetycji, stwarza możliwość wielokrotnych powrotów do głównego tematu czy melodii, a nawet każdorazowo przekształcania tych tematów za pomocą zmiany tonacji, dynamiki, artykulacji, instrumentacji czy nawet interpretacji tego samego zapisu. Ten zabieg oddaje wiernie naturę nostalgii, która wprawdzie jest powrotem, ale powrót nigdy nie jest tożsamy z tym, co było, choćby przez upływ czasu. Utwory o charakterze nostalgicznym często mają budowę ABA1 lub podobną. Wielokrotne 
powtarzanie tematu, często nieco zmodyfikowanego, ale zawsze rozpoznawalnego, cechuje również muzykę towarzyszącą filmom o takim charakterze (wystarczy przywołać Temat Lary z filmu Doktor Żywago). Zabieg ten wykorzystują też kompozytorzy w muzyce towarzyszącej scenom reminiscencji.

Egzemplifikacją moich spostrzeżeń na temat środków artystycznych użytych w celu wywołania wrażenia nostalgii niech będzie, przywoływany już, Polonez a-moll Pożegnanie Ojczyzny - Les Adieux à la Patrie Ogińskiego jako utwór, który nostalgię ma wręcz programowo wpisaną w tytuł. Jest to miniatura fortepianowa, która posiada wiele późniejszych wersji na różny skład instrumentalny i wokalny. Przyjęcie przez kompozytora formy poloneza jest nieprzypadkowe: polonez to taniec typowo polski, przy tym jako taki znany w Europie w XVIII wieku. Ma charakter uroczysty, dworski, dostojny. „Interpretacje semantyczne łączą polonezy z tematyką walki o wolność, z tradycją rycerską i powstańczą" [Encyklopedia muzyczna 1984: 140]. Polonez Ogińskiego wpisuje się w nurt polonezów sentymentalnych. Budowę utworu sprowadzić można do modelu ABA, z powtarzalnymi częściami A i B. Całość, z dyspozycji kompozytora, utrzymana jest $\mathrm{w}$ tempie i charakterze moderato tristamente, czyli umiarkowanie i smutno. Polonez napisany jest $\mathrm{w}$ tonacji a-moll, a więc ułatwiającej wyrażenie smutku. Jednak przełamanie tego smutku w kierunku nostalgii następuje dzięki środkowej części Trio, utrzymanej w tonacji C-dur, w charakterze bardziej jasnej, otwartej, mocnej dynamice forte, jakby przywołującej w myślach minioną świetność i dostojność, by znów da capo al fine powrócić do nastroju powagi i smutku.

Myślę, że ten utwór, oczywiście prawidłowo wykonany, może być przykładem na to, co było głównym celem moich rozważań - czyli pokazanie, że nie trzeba znać losów i zamierzeń kompozytora by, niezależnie od własnych, aktualnych emocji, usłyszeć $\mathrm{w}$ muzyce nostalgię wywołaną przy pomocy czysto muzycznych środków.

Nie sposób słowami opisać charakter utworu muzycznego, gdyż muzyka zawsze wymyka się słowom. Myślę, że wymyka się też nauce, która musi operować słowem i liczbą. Ale, także dzięki filozofom, wiemy już, że nie wszystko, co istnieje, da się zdefiniować, policzyć, a nawet opisać. Myślę, że na podobnych zasadach istnieją i muzyka, i ludzkie uczucia. Oba zjawiska są z natury nie do opisania, ale - tak jak i nostalgia - są przedmiotem naszych najgłębszych doświadczeń.

\section{Bibliografia}

Bouwsma O. K. 1950. The Expression Theory of Art, [w:] M. Black, E. Cliffs (red.), Philosophical Analysis, Ithaca: Cornell University Press.

Budd M. 2014. Muzyka i emocje, przeł. R. Kasperowicz, Gdańsk: Słowo/obraz terytoria. 
Cooke D. 1959. The Language of Music, Oxford: Oxford University Press.

Encyklopedia muzyczna. 1984. Hasło: Chopin Fryderyk, opr. M. Tomaszewski, Kraków: PWN.

Foltyn A. 2013. Neurobiologiczne podstawy postrzegania konsonansu i dysonansu w muzyce, [w:] M. Bogucki, A. Foltyn, P. Podlipniak, P. Przybysz, H. Winiszewska (red.), Neuroestetyka muzyki, Poznań: Wydawnictwo Poznańskiego Towarzystwa Przyjaciół Nauk.

Guczalski K. 2015. Emocje w muzyce. Hanslick $i$ jego fałszywy zwolennik, "Res Facta Nova”, nr 16 (25), s. 35-52.

Ingarden R. 1966. Studia z estetyki, t. II, Warszawa: PWN.

Piotrowicz P. 2016. Grzegorz Turnau: czasy sa zawsze dzisiejsze. Wywiad, „Magazyn O!Kultura", nr 48, źródło elektroniczne: https:/ / muzyka.onet.pl/wywiady/grzegorz-turnau-czasy-sa-zawsze-dzisiejsze-wywiad/fg5kzt (dostęp: 22.01.2019).

Podlipniak P., Przybysz P. 2013. Sztuka, mózg, muzyka: perspektywy neuroestetyki muzyki, [w:] M. Bogucki, A. Foltyn, P. Podlipniak, P. Przybysz, H. Winiszewska (red.), Neuroestetyka muzyki, Poznań: Wydawnictwo Poznańskiego Towarzystwa Przyjaciół Nauk.

Przybysz P. 2013. Emocje muzyczne i ich estetyczne modyfikacje, [w:] M. Bogucki, A. Foltyn, P. Podlipniak, P. Przybysz, H. Winiszewska (red.), Neuroestetyka muzyki, Poznań: Wydawnictwo Poznańskiego Towarzystwa Przyjaciół Nauk.

Schopenhauer A. 1994. Świat jako wola i przedstawienie, t. I, przeł. J. Garewicz, Warszawa: PWN.

Scruton R. 1998. Art and Imagination: A Study in the Philosophy of Mind, South Bend (IN): St. Augustine's Press.

Singer J. L. 1975. The Inner World of Daydreaming, New York: Harper \& Row.

Stróżewski W. 2002. Wokót piękna. Szkice z estetyki, Kraków: Universitas.

Taruffi L., Koelsch S. 2014. The Paradox of Music-Evoked Sadness: An Online Survey. „PLoS ONE", nr 9 (10), źródło elektroniczne: https://doi.org/10.1371/journal.pone.0110490 (dostęp: 22.01.2019).

Zangwill N. 2004. Against Emotion: Hanslick Was Right About Music, „British Journal of Aesthetics", nr 1, źródło elektroniczne: https://doi.org/10.1093/bjaesthetics/44.1.29 (dostęp: 22.01.2019). 
